\title{
$\beta \mathrm{hCG}$ as a prognostic marker in adenocarcinoma of the prostate
}

\author{
M T Sheaff, J E Martin, D F Badenoch, S I Baithun
}

\begin{abstract}
Aims-To assess the importance of immunohistological detection of $\beta$-human chorionic gonadotrophin ( $\beta$ hCG) in localised prostatic adenocarcinoma with regard to prognosis and clinical applications. Methods-Eighty consecutive cases of clinically localised adenocarcinoma of the prostate were studied retrospectively. Immunohistological analysis on formalin fixed, paraffin wax embedded prostate tissue from transurethral resections was related to clinical outcome and survival. Prognosis was also related to tumour grade.
\end{abstract}

Results- hhCG was detected in 12 cases. Nine of these patients were found to have metastases (75\%) at follow up and 11 (92\%) were dead within 18 months. There was no correlation with grade and prognosis in this group. Of the 68 $\beta$ hCG negative cases, 21 had developed metastases (31\%) and $25(37 \%)$ had died within 18 months. In the $\beta$ hCG negative group there was an association between histological grade and survival.

Conclusion-The demonstration of $\beta$ hCG in prostatic adenocarcinoma identifies a group of patients with poor prognosis, irrespective of histological grade. This additional information will be extremely valuable in the subsequent clinical management of such patients.

(f Clin Pathol 1996;49:329-332)

Keywords: prostate, adenocarcinoma, $\beta$-human chorionic gonadotrophin, prognosis.

The clinical management of prostatic adenocarcinoma remains controversial despite the use of grading systems to predict prognosis. The Gleason score is widely used, but unfortunately is not always accurate enough to discriminate between those patients who should be observed, and those who require active treatment by radical surgery, irradiation or hormone therapy. A reliable test that predicts the likelihood of tumour progression would be of enormous benefit in planning treatment of these patients.

Neuroendocrine cells are well described in both normal and neoplastic prostatic tissue. ${ }^{1}$ Many hormones have been identified in these cells, including $\beta$-human chorionic gonadotrophin $(\beta h C G){ }^{2-4}$ The presence of these neuroendocrine cells has not previously been regarded as being of clinical importance.

The $\beta$ subunit of the peptide hormone hCG has also been identified in a variety of germ cell and non-germ cell tumours, and in the former is used to monitor response to treatment and to detect tumour relapse. The significance of positivity in non-germ cell malignancies has been unclear until recently, when it has been found that the presence of $\beta \mathrm{hCG}$ is related to poor response to radiotherapy ${ }^{56}$ and poor prognosis in transitional cell carcinomas of the bladder. ${ }^{7} \beta \mathrm{hCG}$ has also been suggested as a biological marker of prognostic significance in colonic adenocarcinoma. ${ }^{8}$

We therefore investigated the presence of $\beta$ hCG immunohistochemically in tissue sections of clinically localised prostatic adenocarcinoma and related this to tumour grade and prognosis.

\section{Methods}

Eighty consecutive patients with clinically localised adenocarcinoma of the prostate, treated at the Royal London Hospital between 1980 and 1985, were studied. The mean age was 69 years (range 58-84 years). Follow up was available for each patient for a mean of 58 months (range 12-120 months).

Tumour was resected transurethrally and the specimens obtained were fixed in $10 \%$ formol saline. The weight of tissue resected ranged from 5 to $90 \mathrm{~g}$ and between one and 10 blocks were embedded in paraffin wax. Sections $4 \mu \mathrm{m}$ thick were cut and stained with haematoxylin and eosin. Tumour sections were independently assessed by two histopathologists and graded according to the Gleason system giving a score from 2 to 10 . Those patients with a low Gleason score (2-4; group 1 ) were managed by surveillance. Those with higher Gleason score $(>4)$ were offered radical radiotherapy. These were further subdivided into two groups: Gleason scores 5 and 6 (group 2) and 7-10 (group 3 ). In general, hormone manipulation was reserved for those patients who re-presented with painful metastases.

For immunohistochemistry, a random section from each case was dewaxed, placed in $0.3 \%$ hydrogen peroxide and methanol for 15 minutes at room temperature. The sections were then washed in TRIS buffer at $\mathrm{pH} 7 \cdot 6$ and subsequently incubated with normal swine serum for 10 minutes. Sections were then overlaid with rabbit anti- $\beta$ hCG (Dako, High Wycombe, UK) for 20 minutes and incubated with peroxidase conjugated swine anti-rabbit immunoglobulin (Dako) for a further $20 \mathrm{~min}$ utes. The peroxidase complex was visualised using 3,3'diaminobenzidine and hydrogen peroxidase. Mayer's solution was used as counterstain. 
Table 1 Clinical outcome of $\beta h C G$ positive cases

\begin{tabular}{lllll}
\hline Group & $\begin{array}{l}\text { Gleason } \\
\text { score }\end{array}$ & $\begin{array}{l}\text { Number of } \\
\text { patients }\end{array}$ & $\begin{array}{l}\text { Number developing } \\
\text { metastases }\end{array}$ & $\begin{array}{l}\text { Number alive } \\
\text { at 18 months }\end{array}$ \\
\hline 1 & $2-4$ & 4 & 3 & 0 \\
2 & $5-6$ & 2 & 2 & 1 \\
3 & $7-10$ & 6 & 4 & 0 \\
Total & & 12 & 9 & 1 \\
\hline
\end{tabular}

Table 2 Clinical outcome of $\beta$ hCG negative cases

\begin{tabular}{lllll}
\hline Group & $\begin{array}{l}\text { Gleason } \\
\text { score }\end{array}$ & $\begin{array}{l}\text { Number of } \\
\text { patients }\end{array}$ & $\begin{array}{l}\text { Number developing } \\
\text { metastases }\end{array}$ & $\begin{array}{l}\text { Number alive } \\
\text { at 18 months }\end{array}$ \\
\hline 1 & $2-4$ & 28 & 4 & 23 \\
2 & $5-6$ & 20 & 5 & 12 \\
3 & $7-10$ & 20 & 12 & 8 \\
Total & & 68 & 21 & 43 \\
\hline
\end{tabular}

Clinical outcome was related to both Gleason score (grade) and results of $\beta$ hCG immunohistochemistry. $\chi^{2}$ statistics were performed on the data.

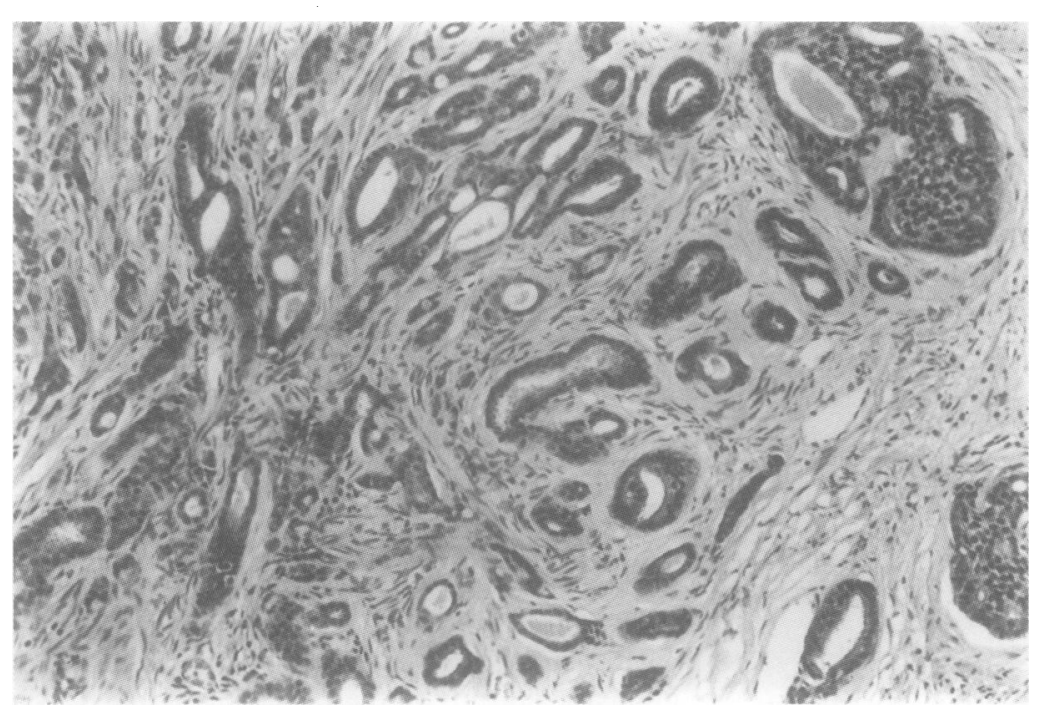

Figure 1 Prostatic carcinoma. (Haematoxylin and eosin, $\times 250$.)

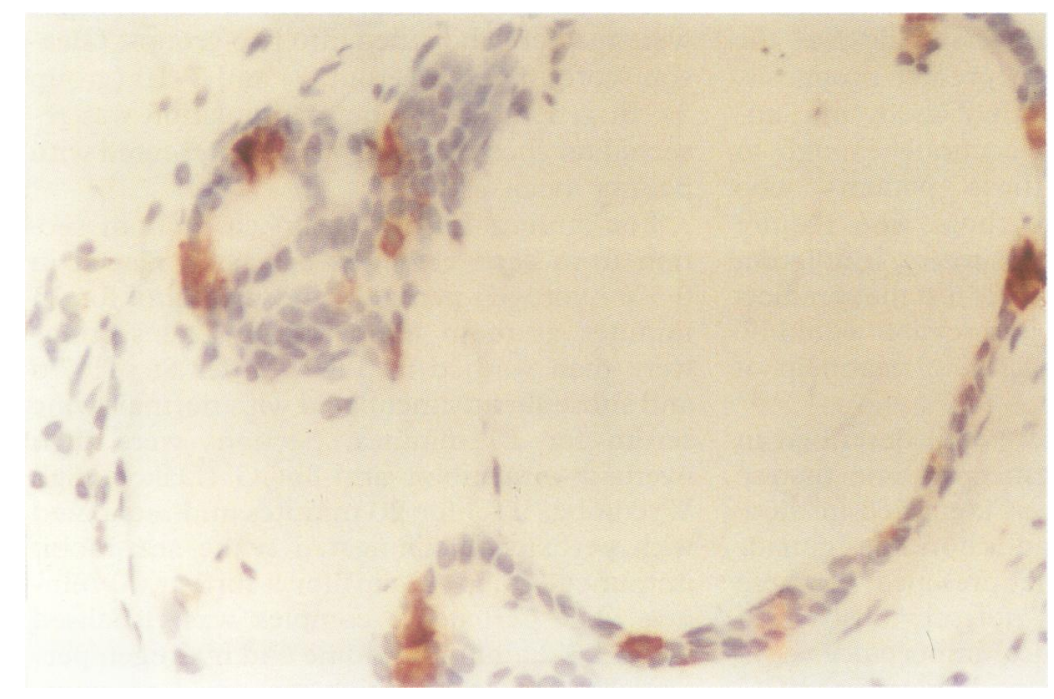

Figure $2 \beta$ BhG positive cells in an adenocarcinoma of the prostate $(\times 250)$.

\section{Results}

The results of $\beta$ hCG immunohistochemistry are presented in tables 1 and 2 . Twelve patients had tumours positive for $\beta$ hCG (figs 1 and 2 ). Of the 68 patients with tumours not expressing $\beta$ hCG, only 21 (31\%) developed metastases. Twenty five $(37 \%)$ of these patients had died within 18 months. In this group there was strong correlation between survival and Gleason score $(p<0.009$; table 2$)$.

Of the patients in the $\beta$ hCG positive group, nine $(75 \%)$ developed metastases and $11(92 \%)$ of the 12 were dead within 18 months $(p<0.004$ and $p<0.0002$, respectively; table 1 ). There was no correlation between Gleason score and prognosis in this group of patients $(p<0 \cdot 13)$.

\section{Discussion}

The management of clinically localised prostatic adenocarcinoma remains difficult despite grading systems aimed at discriminating between those patients with tumours that should be treated aggressively, and those who should be treated symptomatically. Grading and staging systems offer some predictive value, but unfortunately they do not identify those patients with localised disease who progress rapidly and who would probably not benefit from conventional therapeutic regimens. A more reliable predictor of the likelihood of tumour progression would be of enormous benefit in planning the selection of appropriate treatment of patients with localised disease.

Neuroendocrine cells are present in the normal and neoplastic prostate gland ${ }^{1}$ and have also been described in the prostatic urothelium. ${ }^{9}$ They are easily identified in tissue sections using chromogranin or neuron specific enolase markers. A variety of hormones have been demonstrated immunohistochemically within these cells, most commonly serotonin and calcitonin. $\beta$ hCG has also been detected in several published series (table 3 ). The significance of their presence is uncertain, but it has been suggested that they have an endocrine/ paracrine role in growth and development.

$\beta \mathrm{hCG}$ has been recognised in many human malignancies and in some has been related to poor prognosis. In fact, we have shown previously that detection of $\beta$ hCG in transitional carcinomas of the bladder is related to both poor prognosis ${ }^{7}$ and poor response to radiotherapy (especially if there is also squamous metaplasia ${ }^{56}$ ). Campo et $a l^{8}$ also showed that $\beta$ hCG was related to worse prognosis in colorectal carcinomas. Possible reasons for this association were not proposed. Very high serum levels of $\beta$ hCG (>50000 IU/1) also indicate a worse prognosis in germ cell tumours of the testis. ${ }^{17}$

In addition to immunohistochemical demonstration in tissue sections of prostate tumours, $\beta$ hCG concentrations are also increased in both serum and urine from patients with adenocarcinoma of the prostate (table 3 ). However, few of these studies have specifically related the presence of $\beta \mathrm{hCG}$ to survival and none have done so by measuring urinary $\beta \mathrm{hCG}$ concentrations. 
Table $3 \quad \beta h C G$ in adenocarcinoma of the prostate: review of the literature

\begin{tabular}{|c|c|c|c|c|}
\hline Year & Reference & $\begin{array}{l}\text { Number } \\
\text { of cases }\end{array}$ & $\begin{array}{l}\text { Detection } \\
\text { method }\end{array}$ & Comments \\
\hline $\begin{array}{l}1976 \\
1977\end{array}$ & $\begin{array}{l}\text { McManus et el } l^{10} \\
\text { Broder et el }\end{array}$ & $\begin{array}{l}1 \\
1\end{array}$ & $\begin{array}{l}\text { IHC } \\
\text { Serum }\end{array}$ & $\begin{array}{l}\text { ? Prognosis } \\
\text { All stage D } \\
\text { ? Prognosis }\end{array}$ \\
\hline $\begin{array}{l}1980 \\
1983 \\
1984 \\
1986 \\
1987 \\
1987\end{array}$ & $\begin{array}{l}\text { Papapetrou et el }{ }^{12} \\
\text { Fukutani et el }{ }^{13} \\
\text { Purnell et el }{ }^{14} \\
\text { Fetissof et } \mathrm{el}^{4} \\
\text { Abrahamsson } e t \mathrm{el}^{2} \\
\text { Shah et el }\end{array}$ & $\begin{array}{r}2 \\
3 \\
3 \\
2 \\
11 \\
9\end{array}$ & $\begin{array}{l}\text { Urine } \\
\text { Urine 3, serum } 2 \\
\text { IHC } \\
\text { IHC } \\
\text { IHC } \\
\text { IHC }\end{array}$ & $\begin{array}{l}\text { ? Prognosis } \\
\text { ? Prognosis } \\
\text { ? Prognosis } \\
\text { ? Prognosis } \\
\alpha \text { subunit detected } \\
\text { Eight poorly differentiated }\end{array}$ \\
\hline 1988 & Oliver et el ${ }^{16}$ & 2 & IHC & $\begin{array}{l}\text { Prognosis } \\
\text { Both poorly differetiated } \\
\text { ? Prognosis }\end{array}$ \\
\hline 1994 & Bostwick et el ${ }^{3}$ & 26 & IHC & $\begin{array}{l}\text { Radical surgery; } \beta \text { hCG } \\
\text { related to high grade }\end{array}$ \\
\hline
\end{tabular}

Yamanaka et $e l^{25}$ did not detect urinary $\beta$ hCG in their series of prostatic carcinomas (using $\beta$ core fragment antisera). IHC $=$ immunohistochemistry.

Of the 80 cases studied in this investigation, 12 were positive for $\beta \mathrm{hCG}$ in neoplastic epithelial cells of tissue sections. This was found to be related with poor prognosis, irrespective of histological grade. Those tumours that were $\beta$ hCG negative did show close correlation with histological grade. The fact that $\beta$ hCG is raised in both serum and urine of patients with prostate cancer suggests that the immunohistological detection of this hormone is not artefactual, and that the tumour cells are actually producing and secreting it.

$\beta$ hCG increases both serum and prostatic tissue concentrations of testosterone $\mathrm{e}^{1819}$ and prostatic carcinoma is responsive to androgenic stimuli. BhCG may therefore be promoting tumour growth indirectly by increasing testosterone concentrations. (Testosterone is also associated with increased prostatic blood flow. ${ }^{19}$ ) In fact, orchidectomy, anti-androgens and oestrogens have been useful in arresting (or at least retarding) the progression of more advanced prostatic tumour. In addition to a hormonally induced action, $\beta$ hCG may also have a more direct paracrine effect on tumour growth. It has recently been discovered that $\beta$ hCG prolongs survival of cultured transitional carcinoma cells (and has a structure similar to platelet derived growth factor; Iles and Gillot, personal communication). It seems that this increased survival is not due to a proliferative mechanism, but may be due to blocking of apoptosis. It is tempting to speculate that this may in some way relate to bcl-2 expression (an anti-apoptosis protein) as the latter is found in non-androgen dependent prostate cancers and androgen withdrawal has been shown to induce apoptosis. ${ }^{2021} \mathrm{~A}$ further possibility is that $\beta \mathrm{hCG}$ confers tumour cells with a metastasising advantage over the surrounding negative cells by some as yet unknown mechanism.

Another tumour marker, c-erb-B2, has recently been shown to be associated with decreased survival in prostate cancer, ${ }^{223}$ a finding in common with other epithelial tumours. The latter is becoming an important and useful tool in the management of breast carcinoma and in fact immunohistochemistry for this marker is routinely performed on breast tumours in our department prior to planning chemotherapy. For similar reasons, it may be that this marker will be investigated routinely in prostatic tumours. It is likely, however, that $\beta$ hCG or a combination of erb-B2 and $\beta \mathrm{hCG}$ immunohistochemistry will provide more information for the clinician to base therapeutic decisions upon. $\beta$ hCG may in fact be of more use clinically as it is easily detected in urine. This would make it a potentially more widely acceptable and simpler method. In fact it is one of the few available tumour markers that may be useful for screening high risk populations. ${ }^{24}$

In conclusion, the immunohistochemical detection of $\beta$ hCG may be helpful in discriminating those localised tumours that would not benefit from current treatment regimens. These patients would therefore be better managed by either more conservative measures or conversely may benefit from more aggressive chemotherapy or more radical surgery, or both.

Dr Michael Sheaff is supported by the Ernst Schering Research Foundation. Dr Joanne Martin is a Wellcome Trust Fellow.

1 di Sant'Agnese PA. Neuroendocrine differentiation in carcinoma of the prostate: diagnostic, prognostic and therapeutic implications. Cancer 1992;70(Suppl):254-68.

2 Abrahamsson PA, Wadstrom LB, Alumets J, Falkmer S, Grimelius L. Peptide-hormone and serotonin immunoreactive tumour cells in carcinoma of the prostate. Pathol Res Pract 1987;182:298-307.

3 Bostwick DG, Dousa MK, Crawford BG, Wollan PC. Neuroendocrine differentiation in prostatic intraepithelial neoplasia and adenocarcinoma. Am $\mathcal{F}$ Surg Pathol 1994; 18:1240-6.

4 Fetissof F, Bruandet P, Arbeille B, Penot J, Marboeuf Y, Le-Roux J, et al. Calcitonin-secreting carcinomas of the prostate. An immunohistochemical and ultrastructural analysis. Am f Surg Pathol 1986;10:702-10.

5 Jenkins BJ, Martin JE, Baithun SI, Zuk RJ, Oliver RTD, Blandy JP. Prediction of response to radiotherapy in invasive bladder cancer. Br f Urol 1990;65:345-8.

6 Martin JE, Jenkins BJ, Zuk RJ, Blandy JP, Baithun SI. Human chorionic gonadotrphin expression and histological findings as predictors of response to radiotherapy logical findings as predictors of response to radiotherapy in carcinomas of the bladder.
Histopathol $1989 ; 414: 273-7$.

7 Iles RK, Chard T. Human chorionic gonadotrophin expression in bladder cancers: biology and clinical potential f Urol 1991;145:453-8.

8 Campo E, Palacin A, Benasco C, Quesada E, Cardesa A. Human chorionic gonadotrophin in colorectal carcinoma an immunohistochemical study. Cancer 1985;59:1611-16.

9 Kiernan M, Gaffney EF. The endocrine-paracrine cells of von Brunn's nests and glandular metaplasia in the supramontanal prostatic urethra. Histopathology 1990;16: 365-9.

10 McManus LM, Naughton MA, Martinez-Hernandez A. Human chorionic gonadotrophin in human neoplastic cells. Cancer Res 1976;36:3476-81

11 Broder LE, Weintraub BD, Rosen SW, Cohen MH, Tejada F. Placental proteins and their subunits as tumor markers in prostatic carcinoma. Cancer 1977;40:211-16.

2 Papapetrou PD, Sakarelou NP, Braouzi H, Fessas PH. Ectopic production of human chorionic gonadotrophin (hCG) by neoplasms: The value of measurements of immunoreactive hCG in the urine as a screening procedure. Cancer 1980;45:2583-92.

13 Fukutani K, Libby JM, Panko WB, Scardino PT. Human chorionic gonadotrophin detected in urinary concentrates from patients with malignant tumors of the testis, prostate, bladder, ureter and kidney. $\mathcal{F}$ Urol 1983;129:74-7.

14 Purnell DM, Heatfield BM, Trump BF. Immunocytochemical evaluation of human prostatic carcinomas for carcinoembryonic antigen, nonspecific cross-reacting for carcinoembryonic antigen, nonspecific cross-reacting
antigen, $\beta$-chorionic gonadotrophin, and prostate-specific antigen, $\beta$-chorionic gonadotrophin, and
antigen. Cancer Res 1984;44:285-92.

15 Shah VM, Newman J, Crocker J, Antonakopoulos GN, Chapple CR, Collard MJ. Production of $\beta$-human chorionic gonadotrophin by prostatic adenocarcinoma and transitional cell carcinoma of the upper urinary tract. $\mathrm{Br}$ f Exp Pathol 1987;68:871-8.

16 Oliver RT, Stephenson C, Collino CE, Parkinson MC. Clinicopathological significance of immunoreactive betahCG production by bladder cancer. Molecular Biotherapy 1988;1:43-5.

17 Grigor KM. Germ cell tumours of the testis. In: Anthony PP, MacSween RNM, eds. Recent advances in histopathology. Vol 15. Edinburgh: Churchill Livingstone, topathology. Vo

18 Daehlin L. On the effects of oestrogen in the male. Some with prostatic cancer. Scand $\mathcal{f}$ Urol Nephrol Suppl 1985; with prosta

19 Daehlin L, Damber JE, Selstam G, Bergman B. Effects of human chorionic gonadotrophin, oestradiol and es- 
tromustine on testicular blood flow in hypophysectomized rats. Int $\mathcal{F}$ Androl 1985;8:58-68.

20 McDonnell TJ, Troncoso P, Brisbay SM, Logothetis C, Chung LW, Hseih JT, et al. Expression of the protooncogene bcl-2 in the prostate and its association with emergence of androgen-independent prostate cancer. Cancer Res 1992;52:6940-4.

21 Segal NH, Cohen RJ, Haffejee Z, Savage N. BCL-2 protooncogene expression in prostate lationship to the prostatic neuroendocrine cell. Arch Pathol Lab Med 1994;118:616-18. 22 Fox SB, Persad SA, Coleman N, Day CA, Silcocks PB,
Collins CC. Prognostic value of c-erb-B2 and epiderma growth factor receptor in stage Al (T1a) prostatic adenocarcinoma. Br f Unl 1994;74:214-20.

23 Kokuko M, Yoshiki T, Hameguchi A, Okada Y, Tomoyoshi $T$, Higuchi $\mathrm{K}$. Immunohistochemical study of c-erb $\mathrm{T}$, Higuchi $\mathrm{K}$. Immunohistochemical study of c-erb B2 proto-oncogene product in prostatic cancer. Nippon Hi-

24 Beastall GH, Cook B, Rustin GJ, Jennings J. A review of established tumour markers. Ann Clin Biochem 1991;28: 5-18.

25 Yamanaka N, Kawabata G, Morisue K, Hazama M, Nishimura R. Urinary hCG beta-core fragment as a tumor marker for bladder cancer. Nippon Hinyokika Gakkai Zasshi 1993;84:700-6 